(C) 2017

Маренич М. М., кандидат сільськогосподарських наук, Юрченко С. О., кандидат сільськогосподарських наук

Полтавська державна аграрна академія

\title{
ВПЛИВ ДОПОСІВНОЇ ОБРОБКИ НАСІННЯ БІОЛОГІЧНО АКТИВНИМИ РЕЧОВИНАМИ НА РІСТ І РОЗВИТОК РОСЛИН ПШЕНИЦІ ОЗИМОЇ НА ПОЧАТКОВИХ СТАДІЯХ
}

\author{
Рецензент - доктор сільськогосподарських наук, професор М. Я. Шевніков
}

В лабораторних і польових дослідах досліджували вплив різних конщентрачій біологічно активних речовин, протруйників та їх композицій на лабораторну $i$ польову схожість насіння, розвиток рослин на початкових стадіях розвитку. Встановлено, щзо застосування протруйників може не зменшувати енергію проростання насіння, але біологічно активні речовини стимулювали цей показник. Застосування гумінових стимуляторів росту сприяло як збільшенню показника енергї̈ проростання, так і інтенсифікації процесів росту та розвитку рослин. Обробка насіння радостимом сприяла збільшенню польової схожості на 2-4\%, а у варіантах з лігногуматом натрію - на 5-6\%. Застосування у рекомендованих дозах для обробки насіння сприяло збільшенню польової схожості на 7-9 \% для «Гуміфілда» $i$ на 10-15\% для «1R Seedtreatment».

У варіантах з радостимом абсолютно суха маса надземної частини рослин зросла на 13,8-20,6\%, а маса кореневої системи - на 16-25\%. Обробка насіння лігногуматом сприяла збільшенню маси надземної частини $i$ кореневої системи відповідно на 17-19,5\% і 12,7-31\%. У варіантах з гуміфілдом зростання надземної частини становило в середньому $24,8 \%$, а кореневої системи - 26,3\%, а в разі застосування більшої удвічі дози «1R Seedtreatment» - відповідно 37,5 і 40,6 \%! На варіантах, де застосовувалася суміш «Максим Стар 025 FS», 1,5 л/m + «Гуміфілд» $0,5 \mathrm{r} / \mathrm{m}$ в середньому зафіксували збільшення маси надземної частини на 13,9\% та кореневої системи на 15,4\%, а на варіантах із сумішшю «Максим Cmap $025 \mathrm{FS} », 1,5 \mathrm{r} / \mathrm{m}+1 R \mathrm{R}, 0 \mathrm{r} / \mathrm{m}-25,6$ i 26,2\% відповідно. Зроблено висновок про доиільність комбінування сумішей для допосівної обробки насіння 3 метою зменшення негативного впливу протруйників на показники енергї проростання та польової схожості рослин.

Ключові слова: пшениия озима, енергія проростання, схожість, протруйник, стимулятори.

Постановка проблеми. Основним завданням передпосівної обробки насіння сільськогосподарських культур є, передусім, забезпечення захисту рослин від дії шкідників і хвороб. Проте застосування для обробки стимуляторів росту біологічно активних речовин значною мірою сприяе змен- шенню негативної дії протруювачів на енергію проростання та схожість насіння, а також може істотно зменшити кількість їх застосування внаслідок формування кращої стійкості рослин до дії патогенів. До того ж, застосування удосконалених методів обробки насіння може істотно зменшити собівартість виробництва та зменшити пестицидне навантаження на навколишнє середовище й поліпшити якість продукції.

Сучасними дослідженнями вітчизняних і зарубіжних вчених доведено, що обробка насіння $\epsilon$, безперечно, одним 3 найефективніших і найбезпечніших засобів збільшення врожайності сільськогосподарських культур, проте ще існує велика кількість шляхів для його подальшої оптимізації.

Аналіз останніх досліджень та публікацій, у яких започатковано розв'язання проблеми. Багато вчених говорять про ефективність застосування біологічних і хімічних протруйників не тільки для зменшення ураження хворобами, а й для формування стійкості рослин до стресових факторів навколишнього середовища. В дослідах Інституту сільського господарства степової зони НААНУ обробка насіння сумішшю раксилу і антистресу в нормах 0,2 і 0,68 кг/ т насіння призводило до підвищення врожайності на $0,26-0,44$ т/га, а передпосівна обробка насіння сумішшю препарату «Селест Топ 312.5 FS» та мікродобривом «Реаком-плюс-зерно» дала змогу збільшити врожайність на $11-17,2 \%[1,3,4,8,9,12]$. На удобреному органо-мінеральному фоні прибавка врожайності може становити 0,11-0,17 т/га [5].

Проте ймовірним ризиком застосування протруйників може стати істотне зменшення енергії проростання і польової схожості насіння до 65$75 \%[6,10]$. Тому для обробки насіння використовують також стимулятори росту, антиоксиданти, суміші мікроелементів та гумінові речовини. Так у дослідах, які проводили О. С. Давидова, М. М. Сторчак, П. Г. Дульнєв, М. Д. Аксиленко, Т. В. Матюша, Н. М. Мальцева, А. П. Гаєвський, К. Ю. Дерев'янко та інших, де визначали вплив «Радостиму», лігногумату калію та його комплексу 
iз мікроелементами, антиоксидантів (селенату натрію, сульфіту натрію, саліцилової та бензойної кислот) та інших речовин встановлено, що всі препарати забезпечили накопичення вегетативної маси порівняно 3 контролем на 10-23 \% більше, а сумарна довжина зародкових коренів зросла на $30 \%$; кількість бічних коренів зросла на $45 \%$, а їх сумарна довжина - на $70 \%$. Зростала також і кількість бічних коренів на 6-73\%, а їх сумарна довжина - на 37-74 \% [2, 3, 7, 11].

Оскільки на ринку України пропонується надзвичайно великий асортимент препаратів, то дослідження їх впливу на проростання, ріст рослин і формування врожайності будуть актуальними тривалий час. У цьому аспекті необхідно зазначити, що далеко не всі препарати відповідають заявленим характеристикам. Дуже важливим чинником є дотримання відповідних регламентів застосування препаратів у виробничих умовах.

Досить часто агрономи не отримують очікуваної прибавки врожайності i, як наслідок, у подальшому відмовляються від ефективних методів управління продукційним процесом, маючи в своєму розпорядженні набагато простіші в користуванні мінеральні добрива та засоби захисту рослин.

Метою досліджень було визначення впливу передпосівної обробки насіння хімічними препаратами для захисту рослин, стимуляторів росту та їх комбінацій на схожість та морфологічні показники рослин, пошук оптимального варіанту для передпосівної обробки. Для цього були сформульовані наступні завдання:

1) В лабораторних дослідах встановити вплив передпосівної обробки препаратами та їх сумішами на енергію проростання (ЕП), лабораторну схожість (ЛС) та морфологічні показники проростків;

2) У польовому багатофакторному досліді визначали вплив цих же варіантів на польову схожість (ПС), морфологічні показники розвитку рослин 15-денного віку.

Матеріал і методика проведення досліджень. Лабораторні досліди проводилися в лабораторії якості зерна Полтавської державної аграрної академії. Матеріалом для експерименту стали зразки насіння сортів пшениці озимої Сагайдак, Богдана, Вдала, Левада, Славна, які використовувалися також і для польових дослідів. Насіння оброблялось рекомендованими дозами протруйників та стимуляторів росту гумінового походження 3 розрахунку 8 л розчину на тону насіння.
Повторність лабораторного досліду 12кратна, повторність польового досліду - триразова. Біометричні показники визначали в лабораторному досліді відразу після визначення схожості, в польовому - на 15-й день після отримання сходів. Для обробки результатів використовувалися метод багатофакторного дисперсійного аналізу, статистичну обробку результатів здійснювали за допомогою програми STATISTICA 10.0 .

Результати досліджень. Сучасні протруйники, в цілому, можуть не призводити до істотного зменшення енергії проростання та лабораторної схожості, проте застосування «Радостиму» та лігногумату натрію дає змогу збільшити енергію проростання на 3-4\%. Лабораторна схожість при цьому майже не змінювалася, хоча як показують результати дисперсійного аналізу вплив «Радостиму» та лігногумату натрію теж статистично достовірний (табл. 1).

Найкраще позитивну дію стимуляторів росту видно за масою проростків, особливо це помітно на варіанті з лігногуматом натрію. Так, у сорту Сагайдак маса проростків зросла в середньому на 0,03 г, що становить 21,3\% порівняно 3 контролем. У сорту Богдана позитивний ефект становив 22,3\%, а у сорту пшениці Вдала маса проростків у цьому ж варіанті була на 26,2 \% більшою.

У другому досліді досліджували ці та інші препарати в лабораторних і польових умовах. Результати статистичної обробки даних експерименту свідчать про незаперечний позитивний вплив стимуляторів росту на польову схожість та ріст і розвиток рослин на початкових стадіях розвитку.

Як бачимо 3 даних таблиці 2, обробка насіння препаратом «Максим Стар» практично не впливає на енергію проростання та лабораторну схожість насіння, а обробка насіння стимуляторами позитивно вплинула на ці показники та масу проростка. Найкращі результати отримані на варіанті із застосуванням нового препарату «1R Seedtreatment» в нормі 1 кг/т насіння.

Значно помітніший вплив обробки насіння на показники польової схожості та формування маси рослин на початкових етапах розвитку. Відразу зазначимо, що польова схожість насіння в досить великій мірі залежить від агрокліматичних факторів - наприклад, у 2015 році сходи були отримані на початку зими, були слабко розвиненими, але навіть усереднені дані свідчать про ефективність передпосівної обробки насіння. 
СІЛЬСЬКЕ ГОСПОДАРСТВО. РОСЛИННИЦТВО

1. Вилив передпосівної обробки насіння на лабораторні показники насіння

\begin{tabular}{|l|c|c|c|}
\hline \multicolumn{1}{|c|}{ Варіант } & $\begin{array}{c}\text { Енергія } \\
\text { проростання, \% }\end{array}$ & $\begin{array}{c}\text { Лабораторна } \\
\text { схожість, \% }\end{array}$ & $\begin{array}{c}\text { Маса } \\
\text { проростка, г }\end{array}$ \\
\hline \multicolumn{3}{|c|}{ Сагайдак } \\
\hline Контроль (без обробки) & 86 & 94 & 0,141 \\
«Максим Стар 025 FS», 1,5 л/т & 86 & 94 & 0,120 \\
«Радостим» & 89 & 95 & 0,144 \\
Лігногумат натрію & 90 & 95 & 0,171 \\
\hline \multicolumn{3}{|c|}{ Богдана } \\
\hline Контроль (без обробки) & 87 & 94 & 0,139 \\
«Максим Стар 025 FS», 1,5 л/т & 87 & 94 & 0,147 \\
«Радостим» & 90 & 95 & 0,133 \\
Лігногумат натрію & 90 & 95 & 0,170 \\
\hline \multicolumn{2}{|c|}{ Вдала } \\
\hline Контроль (без обробки) & 86 & 94 & 0,126 \\
«Максим Стар 025 FS», 1,5 л/т & 86 & 95 & 0,151 \\
«Радостим» & 89 & 96 & 0,128 \\
Лігногумат натрію & 89 & 96 & 0,159 \\
НІР & 1,7 & 0,027 \\
\hline
\end{tabular}

Обробка насіння «Радостимом» сприяла збільшенню польової схожості на $2-4 \%$, а у варіантах 3 лігногуматом натрію - на 5-6 \%. Кращий ефект спостерігався в разі обробки насіння сучасними препаратами гумінового походження «Гуміфілдом» та $1 \mathrm{R}$. Перший з них вже отримав схвальні відгуки виробничників, другий тільки вийшов на український ринок.

Застосування цих речовин у рекомендованих дозах для обробки насіння сприяло збільшенню польової схожості на 7-9 \% для гуміфілда і на $10-15 \%$ для «1R Seedtreatment». Таким чином ці препарати виявилися значно ефективнішими. Зважаючи на те, що все таки існує імовірність зниження польової схожості внаслідок обробки протруйником ці препарати були застосовані для сумішей 3 «Максим Стар» і результат також виявився позитивним - 3-7 \% в суміші «Максим Стар 025 FS», 1,5 л/т + «Гуміфілд» 0,5 л/т та 6$11 \%$ для суміші «Максим Стар 025 FS», 1,5 л/т + «R» 1,0 л/т.

Значно помітніший позитивний ефект обробки спостерігався на розвитку рослин. У варіантах 3 «Радостимом» абсолютно суха маса надземної частини рослин зросла на $13,8-20,6 \%$, а маса кореневої системи - на 16-25\%. Обробка насіння лігногуматом сприяла збільшенню маси надземної частини і кореневої системи відповідно на 17-19,5\% i 12,7-31\%. Проте найбільший ефект дали нові препарати «Гуміфілд» $\mathrm{i}$ «1R». У варіантах 3 «Гуміфілдом» зростання надземної частини становило в середньому $24,8 \%$, а кореневої системи $-26,3 \%$, а в разі застосування більшої удвічі дози «1R Seedtreatment» - відповідно 37,5 i $40,6 \%$ !

Додавання цих препаратів у суміші для передпосівної обробки також мало позитивний ефект. На варіантах, де застосовувалася суміш «Максим Стар 025 FS», 1,5 л/т + «Гуміфілд» 0,5 л/т в середньому зафіксували збільшення маси надземної частини на $13,9 \%$ та кореневої системи на $15,4 \%$, а на варіантах із сумішшю «Максим Стар $025 \mathrm{FS} », 1,5$ л/т + «1R» 1,0 л/т - 25,6 і 26,2\% відповідно.

Висновок. У період сівби пшениці озимої досить часто складаються несприятливі агрокліматичні умови, що в першу чергу пов'язано $з$ дефіцитом вологи, тому отримання повноцінних $\mathrm{i}$ сильних сходів - дуже важливе й складне завдання для виробництва. Одним із шляхів його розв'язання $є$ застосування стимуляторів росту. Обробка насіння такими препаратами як «Радостим», лігногумат калію, «Гуміфілд», «1R Seedtreatment» істотно збільшує шанси отримати дружні і добре розвинені сходи, які мають перспективу в подальшому забезпечити зимостійкість посівів і сформувати високі рівні врожайності. Додавання цих препаратів до сумішей 3 протруйниками насіння також сприяє підвищенню польової схожості та інтенсивності наростання вегетативної маси. 
2. Вплив передпосівної обробки насіння на показники схожості та накопичення сухої маси в період осінньої вететації (2014-2016 рр.)

\begin{tabular}{|c|c|c|c|c|c|c|}
\hline \multirow{2}{*}{ Варіант } & \multirow{2}{*}{$\mathrm{E} \Pi, \%$} & \multirow{2}{*}{$\begin{array}{c}\text { ЛС, } \\
\%\end{array}$} & \multirow{2}{*}{$\begin{array}{l}\text { Маса проро- } \\
\text { стка, Г }\end{array}$} & \multirow{2}{*}{$\Pi C, \%$} & \multicolumn{2}{|c|}{$\begin{array}{c}\text { Маса сухої речовини, } \\
\text { г/100 рослин }\end{array}$} \\
\hline & & & & & $\begin{array}{c}\text { Надземна } \\
\text { частина }\end{array}$ & $\begin{array}{c}\text { Коренева } \\
\text { система }\end{array}$ \\
\hline \multicolumn{7}{|c|}{ Левада } \\
\hline Контроль (без обробки) & 85 & 93 & 0,13 & 75 & 2,136 & 0,615 \\
\hline «Максим Стар 025 FS», 1,5 л/т & 85 & 93 & 0,10 & 71 & 2,041 & 0,639 \\
\hline «Радостим», 0,25 л/т & 87 & 93 & 0,13 & 79 & 2,478 & 0,753 \\
\hline Лігногумат натрію 0,5 л/т & 87 & 93 & 0,14 & 81 & 2,499 & 0,767 \\
\hline «Гуміфілд», 0,5 л/т & 87 & 93 & 0,17 & 83 & 2,456 & 0,767 \\
\hline «1R»1,0 л/т & 89 & 95 & 0,19 & 86 & 2,829 & 0,835 \\
\hline $\begin{array}{l}\text { «Максим Стар } 025 \text { FS», 1,5 л/т } \\
+ \text { «Гуміфілд»0,5 л/т }\end{array}$ & 88 & 93 & 0,15 & 78 & 2,296 & 0,659 \\
\hline $\begin{array}{l}\text { «Максим Стар } 025 \text { FS», } 1,5 \text { л/т } \\
+ \text { «1R» } 1,0 \text { л/т }\end{array}$ & 88 & 93 & 0,17 & 81 & 2,573 & 0,752 \\
\hline \multicolumn{7}{|c|}{ Славна } \\
\hline Контроль (без обробки) & 86 & 92 & 0,13 & 70 & 2,021 & 0,568 \\
\hline «Максим Стар 025 FS», 1,5 л/т & 85 & 91 & 0,13 & 67 & 1,872 & 0,589 \\
\hline «Радостим», 0,25 л/т & 88 & 93 & 0,13 & 74 & 2,300 & 0,662 \\
\hline Лігногумат натрію 0,5 л/т & 86 & 92 & 0,16 & 76 & 2,471 & 0,744 \\
\hline «Гуміфілд», 0,5 л/т & 89 & 93 & 0,15 & 79 & 2,684 & 0,761 \\
\hline «1R»1,0 л/т & 90 & 94 & 0,17 & 85 & 2,911 & 0,902 \\
\hline $\begin{array}{l}\text { «Максим Стар } 025 \mathrm{FS} », 1,5 \text { л/т } \\
+ \text { «Гуміфілд» } 0,5 \text { л/т }\end{array}$ & 87 & 92 & 0,16 & 77 & 2,322 & 0,670 \\
\hline $\begin{array}{l}\text { «Максим Стар } 025 \text { FS», } 1,5 \text { л/т } \\
+ \text { «1R» } 1,0 \text { л/т }\end{array}$ & 88 & 93 & 0,16 & 81 & 2,613 & 0,752 \\
\hline \multicolumn{7}{|c|}{ Смуглянка } \\
\hline Контроль (без обробки) & 85 & 92 & 0,13 & 72 & 2,318 & 0,707 \\
\hline «Максим Стар 025 FS», 1,5 л/т & 85 & 92 & 0,13 & 68 & 2,253 & 0,658 \\
\hline «Радостим», 0,25 л/т & 88 & 93 & 0,15 & 76 & 2,794 & 0,883 \\
\hline Лігногумат натрію 0,5 л/т & 88 & 93 & 0,16 & 77 & 2,769 & 0,796 \\
\hline «Гуміфілд», 0,5 л/т & 89 & 93 & 0,15 & 79 & 2,936 & 0,849 \\
\hline «1R»1,0 л/т & 89 & 94 & 0,18 & 82 & 3,153 & 0,901 \\
\hline $\begin{array}{l}\text { «Максим Стар } 025 \text { FS», 1,5 л/т } \\
+ \text { «Гуміфілд» 0,5 л/т }\end{array}$ & 86 & 93 & 0,13 & 75 & 2,768 & 0,862 \\
\hline $\begin{array}{l}\text { «Максим Стар } 025 \mathrm{FS} », 1,5 \text { л/т } \\
+ \text { «1R» } 1,0 \text { л/т }\end{array}$ & 87 & 94 & 0,14 & 78 & 2,943 & 0,876 \\
\hline$H I P_{05}$ & 2,4 & 2,3 & 0,042 & & & \\
\hline
\end{tabular}

$\mathrm{HIP}_{05} 2014=5,38$

$\mathrm{HIP}_{05} 2015=12,75$

$\mathrm{HIP}_{05} 2016=9,22$

\section{БІБЛІОГРАФІЯ}

1. Бабаянц Л. T. Расовый состав Blumeriagraminis (DC) Speerf.sp.tritici в Степи Украины и эффективность Рт-генов / Л. Т. Бабаянц, О. В. Бабаянц, В. А. Трасковецкая : мате- ріали міжнар. науково-практич. конф. [«Інтегрований захист рослин. Проблеми та перспективи»] (Київ, 13-16 листопада 2006 р.). - К., 2006. C. $100-101$. 


\section{СІЛЬСЬКЕ ГОСПОДАРСТВО. РОСЛИННИЦТВО}

2. Вплив біологічно активних речовин i мікроелементів на здатність озимої пшениці використовувати фосфор трикальцій фосфату / [Давидова О. Є., Аксиленко М. Д., Мокринський В. М. та ін.] [Електронний ресурс] // Физиология и биохимия культурных растений. - 2011. T. 43. - №4. - С. 307-615. - Режим доступу : http://www.nbuv.gov.ua/old_jrn/chem_biol/fbkr/20 11_4/fbkr_43_4-307.pdf.

3. Дудка $Є$. Л. Захист озимої пшениці від хвороб / Є. Л. Дудка, П. Ліпсс. - Дніпропетровськ : Нова ідеологія, 1999. - 19 с.

4. Желязков О. І. Вплив агротехнічних прийомів вирощування на зернову продуктивність пшениці озимої по стерньовому попереднику / O. І. Желязков // Бюлетень Інституту сільського господарства степової зони. - 2014. - №7. C. 133-139.

5. Кузьменко Н. В. Вплив хімічних протруйників на посівні якості насіння пшениці м'якої озимої / Н. В. Кузьменко, А. Є. Литвинов, I. I. Клименко, С. М. Волошина // Вісник Центру наукового забезпечення АПВ Харківської області. - 2015. - Вип. 19. - С. 60-67.

6. Кузьменко Н. В. Передпосівна обробка насіння пшениці м'якої озимої (Triticumaestivum 1.) в захисті від кореневих гнилей / Н. В. Кузьменко, А. Є. Литвинов, Г. К. Фурсова // Вісник Центру наукового забезпечення АПВ Харківської області. - 2014. - Вип. 17. - С. 209-215.

7. Мальцева Н. М. Вплив біологічно активних речовин та їх композицій на вміст фотосин- тетичних пігментів у листках озимої пшениці в умовах дефіциту фосфору / Н. М. Мальцева, А. П. Гаєвський, К. Ю. Дерев’ янко [Електронний pecypc] // Физиология и биохимия культурных растений. - 2011. - Т. 43. - №5. - С. 403-411. Режим доступу : http:/www.nbuv.gov.ua/ old_jrn/chem_biol/ fbkr/2011_5/fbkr_43_5-403.pdf.

8. Наукові основи агропромислового виробництва в зоні Степу України : наукове видання. К. : Аграр. наука, 2010. - 984 с.

9. Нетіс I. T. Характер осені й весни та посіви озимої пшениці : [монографія] / I. Т. Нетіс. Херсон : Айлант, 2004. - 152 с.

10. Попов C. I. Вплив протруєння насіння на врожайність пшениці озимої після пізніх попередників / С. І. Попов, С. В. Авраменко // Вісник Центру наукового забезпечення АПВ Харківської області. - 2015. - Вип. 19. - С. 81-85.

11. Хіміко-біологічні засоби для підвищення використання рослинами озимої пшениці фосфору 3 гліцерофосфату кальцію / [О. С. Давидова, М. М. Сторчак, П. Г. Дульнєв та ін.] [Електронний ресурс] // Физиология и биохимия культурных растений. - 2011. - Т. 43. - №1. - С. 47-56. Режим доступу : http:/www.nbuv.gov.ua/ old_jrn/chem_biol/fbkr/2011_1/fbkr_43_1-47.pdf.

12. Ярошенко C. C. Вплив протруйників насіння на продуктивність пшениці озимої / С. С. Ярошенко // Бюлетень Інституту сільського господарства степової зони НААН України. Дніпропетровськ, 2012. - №2. - С. 137-139. 